\title{
Environmental noise and light in an university printing workshop in San José, Costa Rica
}

\author{
Lourdes Arce Espinoza ${ }^{1} \&$ Julián Monge Nájera² \\ ${ }^{1}$ Servicio Médico, Universidad Estatal a Distancia, 474-2050 San Pedro, Montes de Oca, San José, Costa Rica; larce@uned.ac.cr \\ ${ }^{2}$ Vicerrectoría de Investigación, Universidad Estatal a Distancia, 474-2050 San Pedro, Montes de Oca, San José, Costa Rica; julianmonge@gmail.com
}

Received 17-XI-2010 Corrected 23-II-2011 Accepted 11-III-2011

\begin{abstract}
Concern for inadequate exposure to physical factors in the working environment began in the mid 20th. Century. The subject has been widely studied in industrial nations, but in Central America there are few published studies, so we measured two environmental factors in a university press workshop in Costa Rica, from April 05 to 16, 2010, a period in which production is high. With a calibrated Extech HD450 light meter we did at least three measurements of light along the workday (considering changes in natural lighting). We selected the measurement points where certain illumination is needed for proper operation of industrial machinery. We also made 20 real-time measurements of noise with a certified Extech sound meter, in the offset press room, where there is noisy industrial machinery. We found inadequate noise and lighting levels, and concluded that staff are exposed to inappropriate health conditions, so we recommend the relocation of lamps and periodical audiometric tests.
\end{abstract}

\section{KEY WORDS}

Working environment, physical agents, university printing workshop.

\section{RESUMEN}

Desde hace más de dos milenios se sabe que las condiciones laborales afectan la salud, pero fue hasta mediados del siglo XX que en el medio industrial surgió una preocupación por la exposición inadecuada a factores físicos. Aunque el tema ha sido muy estudiado en países industrializados, en América Central hay muy pocos estudios, por lo que medimos dos factores ambientales en una imprenta universitaria de Costa Rica, del 05 al 16 de abril del 2010, periodo en el cual la actividad es mayor. Hicimos al menos tres mediciones de iluminación lo largo del día laboral con el fin de contemplar los cambios en la iluminación natural, con un luxómetro Extech HD450 calibrado. Elegimos los puntos de medición donde se requieren ciertos niveles de luz para una operación adecuada de la maquinaria industrial. Además hicimos 20 mediciones de ruido en tiempo real en la prensa, que es el equipo más ruidoso, con un sonómetro certificado Extech. Hallamos exceso de ruido e iluminación deficiente, concluyendo que el personal está potencialmente expuesto a condiciones inadecuadas de salud, por lo que recomendamos reubicar las lámparas y hacer audiometrías periódicas.

\section{PALABRAS CLAVE}

Ambiente laboral, agentes físicos, imprenta universitaria.
The relationship between working conditions and the health of workers was mentioned in the works of Hippocrates, but it was not until the $20^{\text {th }}$ Century that the matter received widespread scientific attention. Researchers found that, apart from dangerous chemicals, light and noise are among the main physical factors affecting health (Ahmed et al. 2001, Chacín-Almarza et al. 2002).

When light levels are inadequate, workers suffer from headaches, eye strain and general stress (Rodríguez \& Alonzo 2004). On the other, proper lighting reduces the risk of accidents, and workers report that they feel better, less stressed and more alert in properly lit workshops (Van Bommel \& Van den Beld 2004).

In the past, noise was considered more as annoying than as dangerous. However, we now know that it can lead to stress, sleep disorders, chronic fatigue, hearing loss and even fetal and heart problems, as well as learning problems, agressiveness and loss of concentration (Chacín-Almarza et al. 2002, Chávez 2006, Montiel-López et al. 2006). 
Noise related problems represent $41 \%$ of work-related health problems in Mexico (Loera-González et al. 2002) and are among the "ten top diseases" related with working conditions in Venezuela and the USA (Montiel-López et al. 2006). Their economical effects include costs of health treatment, low productivity, accidents and reduced value of infrastructure (Van Bommel \& Van den Beld 2004).

There are no equivalent studies in Central America and there is only one previous study in Costa Rican printing shops, in which two departments were found to have insufficient light and one was found to have excessive noise levels, endangering the health of staff and other users of the facilities (Arce \& Monge 2010). However, this single studied did not have any equivalent data for comparisons; for that reason, we made this study in another university printing shop, and found the same unsatisfactory conditions, suggesting that the problem may be widespread in the country.

\section{METHODOLOGY}

We evaluated the workstations in a university printing workshop in San José, Costa Rica, from April 5 through 16, 2010. We chose this time period because the workshop works at full capacity in April, and repeated the morning light measurements in the afternoon to allow for variations in natural light. We made 20 noise and 20 light measurements per day at each point.

\section{Light}

We set 8 measurement points in the digital printing room and 27 in the offset printing room and used an Extech HD450 luxometer. We chose the points after consulting the staff about where they needed the best lighting to operate the machines and used the official Costa Rican norm (Nr. 31-08-06-2000) which sets a minimum of 300 lux (INTECO 2000).

\section{Noise}

We set eight measurement points in the digital printing room and 27 in the offset printing room and used a certified octave band Extech sonometer in real time. We chose the printing press because it is the noisiest machine in the workshop.

We used a color coded classification: green (under 80 decibels), yellow (80-85 decibels) and red (over 85 decibels), according to norm 31-09-16-2000 (INTECO 2000). We thought of this "traffic light" color codes because they are easy to understand for non-specialists (green: safe, yellow: intermediate, red: danger).

\section{Ethics}

We followed all pertinent ethical guidelines described by Emanuel et al. (2000). Our study provides original and rigorously collected scientific information on a previously unknown subject (conditions in Costa Rican printer workshops); the results can be used to improve health care in the studied institution and similar environments, and no individual identities are presented or can be identified. Furthermore, the project was approved by the University Research Division, which includes ethics among its criteria and no medical treatment was applied: in fact, we studied workstations, not humans.

\section{RESULTS}

\section{Light}

In the digital printing room more than half of the points had an acceptable level (Fig.1). A larger proportion of workstations had insufficient light in the offset shop (Fig. 2).

\section{Noise}

We grouped noise levels in the same, easy to understand "traffic light" way (Figs. 3 and 4).

\section{DISCUSSION}

We could not compare our earlier data (Arce \& Monge 2010) with previous studies because we were unable to find equivalent published studies on the light and noise levels of any other university printing press, not only for Costa Rica, but for all of Latin America. Now that we have this second study, it is clear that conditions are equally unsatisfactory in both university printing shops.

\section{Light}

In both buildings, the lighting is poor: almost half of the measurements are within the 300 to 400 Lux range. Insufficient lighting can cause decreased productivity, fatigue, headaches (Guerrero et al. 2006), stress and visual disturbances (Rodriguez et al. 2004, Su et al. 2006). Insufficient lighting can favor accidents caused by falls or by sliding boxes or machinery. In addition, the use of hydraulic presses and an industrial guillotine is highly hazardous under these insufficient light conditions (Wang \& Zhang 2007). 


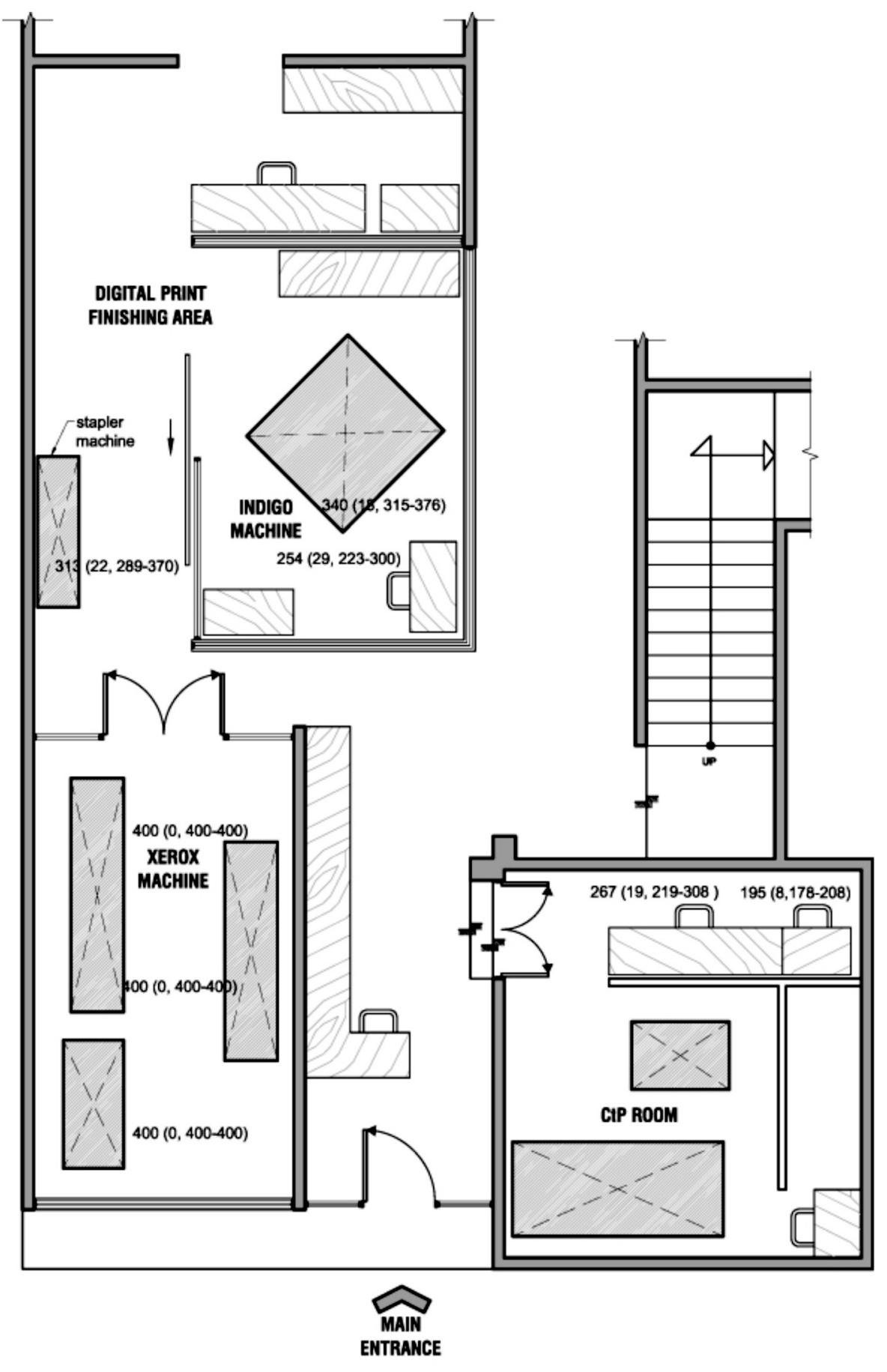

FIG. 1. Light levels in the digital printing section (Scale 1:75). In this and in next figures, the first number given besides each working station is the mean, the numbers in parentheses are the standard deviation and the range (minimum-maximum). 


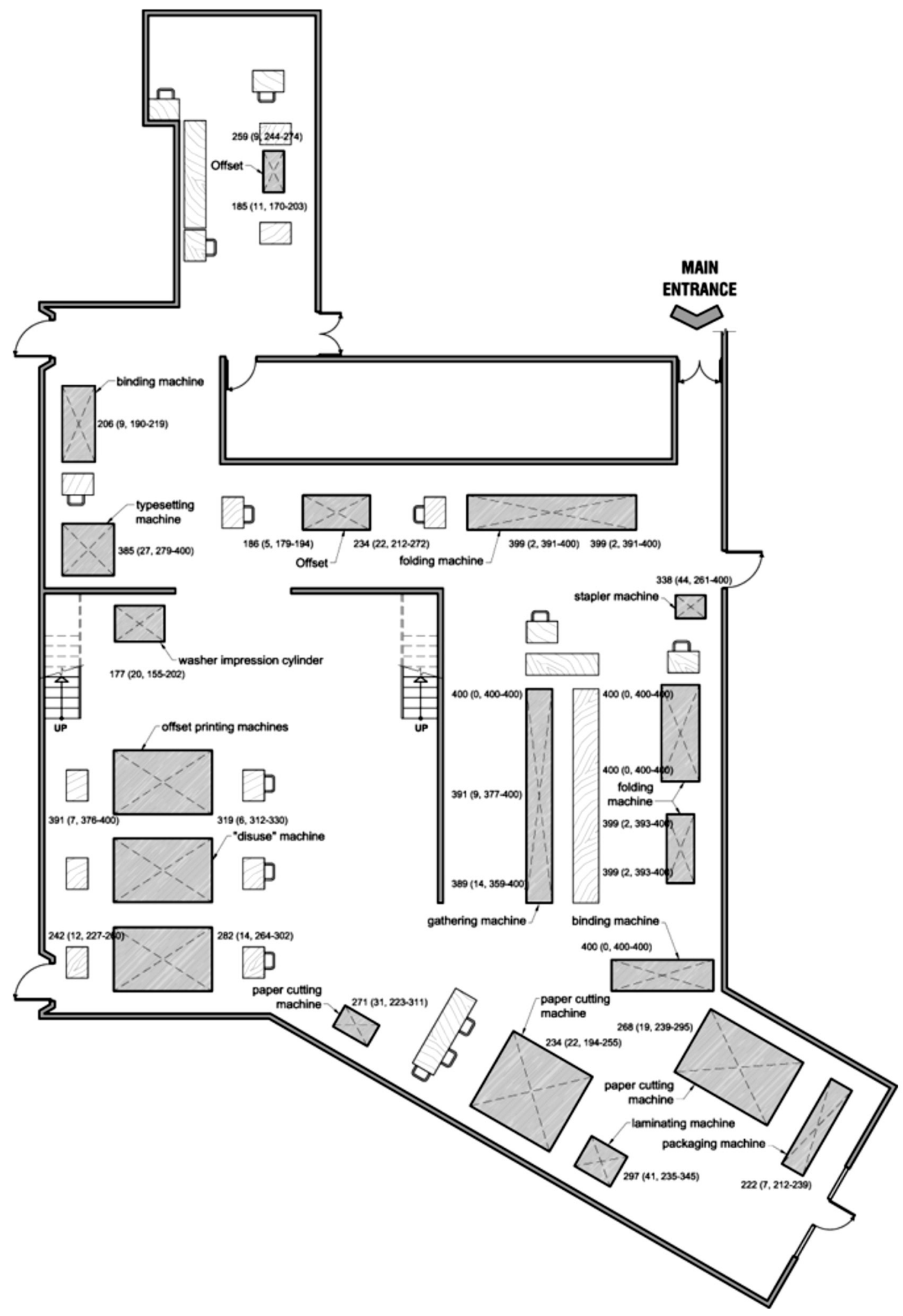

FIG. 2. Light levels in the offset workshop (Scale 1:100). 


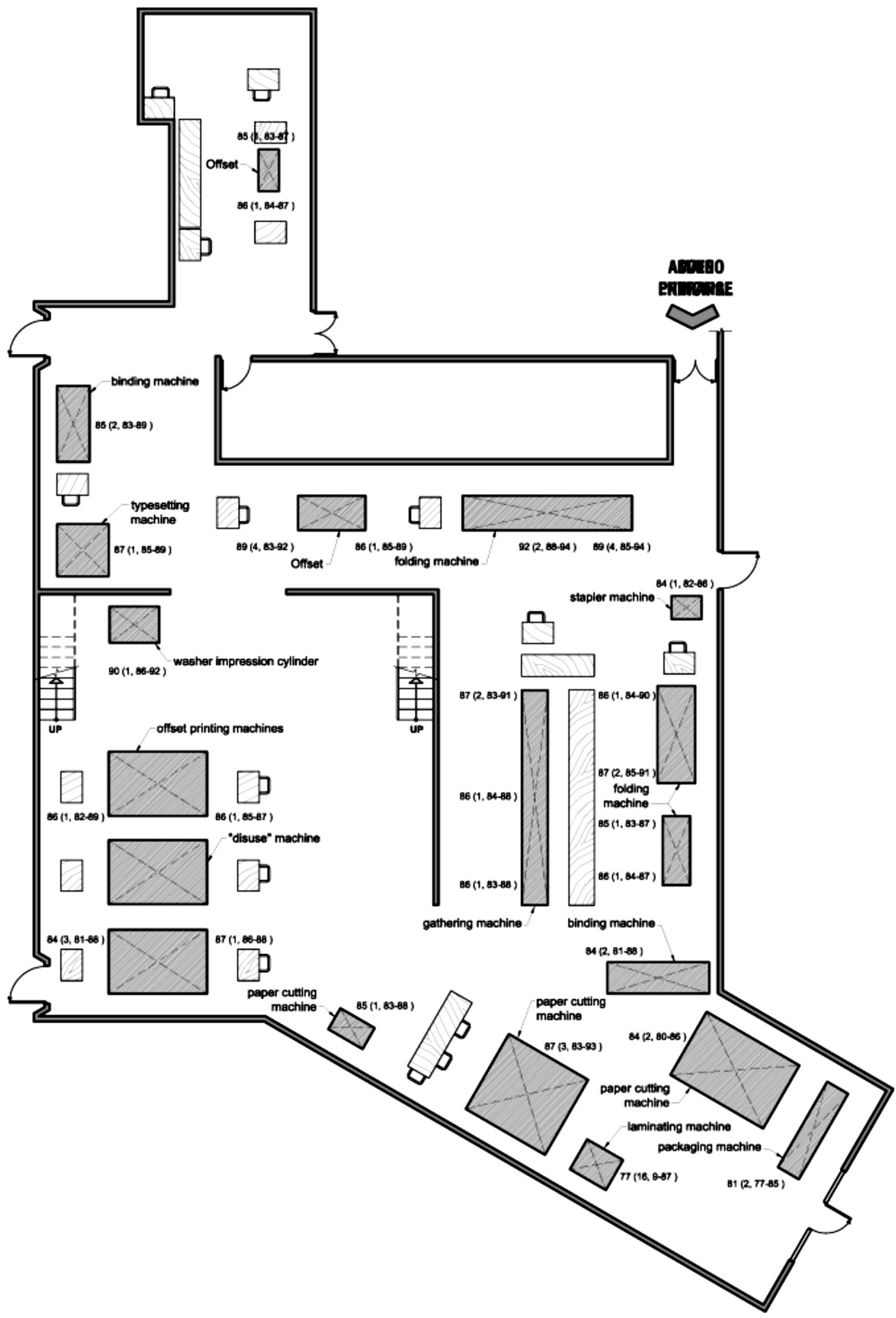

FIG. 3. Noise levels in the offset workshop (Scale 1:100). 


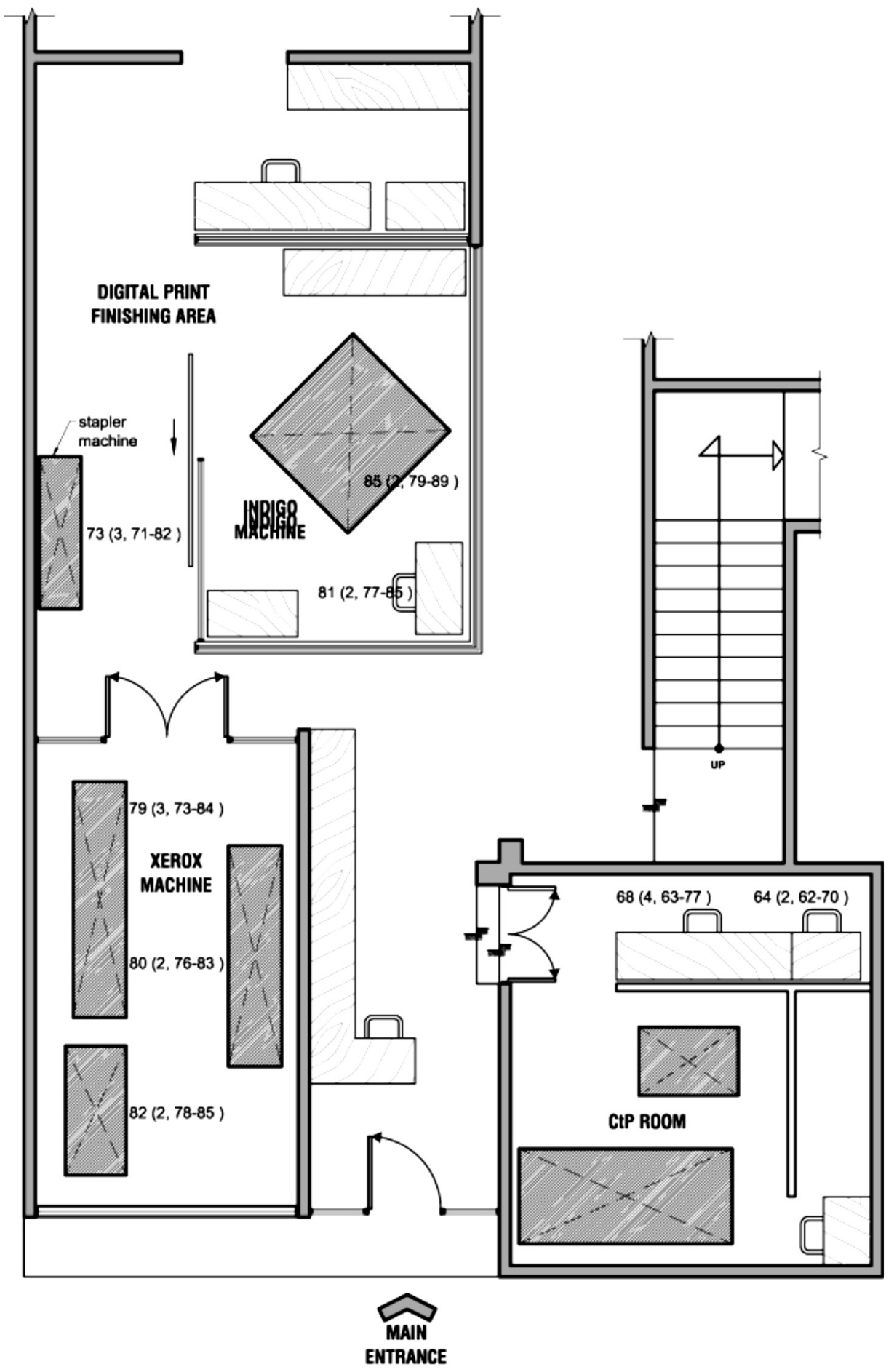

FIG. 4. Noise levels in the digital printing section (Scale 1:75). 


\section{Noise}

According to international standards, in the digital printing building the noise level is within recommended limits $95 \%$ of the time, thanks to the use of advanced technology: there is no noise problem in this section. Nevertheless, the offset workshop significantly exceeds the acceptable level of noise. Without the proper use of ear protecting devices, there is the possibility of communication interference, chronic fatigue, high blood pressure and aggression (Babisch et al. 2005, Stanfeld 2006, Chávez 2007, De Kluizenaar et al. 2009). Periods of rest can allow recovery of the hearing threshold, but generally the problem progresses towards deafness when there is chronic exposure (Hernández \& Gutiérrez 2006, La Torre et al. 2007,Otárola et al. 2008,).

Strong persistent noise produces high levels of stress associated with hormonal changes that can lead to cardiovascular disease (short-and medium-term acute myocardial infarction) and a higher incidence of new cases of hypertension, or, in patients already diagnosed with hypertension, to difficult to manage forms of the condition (Belojevi et al. 2008, Selander et al. 2009).

\section{RECOMMENDATIONS}

This printing shop, and others in the same condition, should:

- Increase natural lighting by opening skylights and additional windows.

- Relocate the lamps closer to the workstations.

- Perform periodic audiometric screening for early detection of any hearing damage in workers.

- Perform clinical audiometry in workers who fail the screening audiometry to determine the type of hearing loss.

- Enforce norms to wear ear protectors in the offset shop.

- Develop a hearing conservation program with the Occupational Health Division.

- Educate staffabout risk exposure and health implications

\section{ACKNOWLEDGEMENTS}

We appreciate the support of Carlos Picado and the workshop staff, the assistance of Andrea Sanchez and two anonymous reviewers for comments that helped improve an earlier version. This study was financed by Vicerrectoría de Investigación, UNED.

\section{REFERENCES}

Ahmed, H.O., J.H. Dennis, O. Badran, M. Ismail, S.G. Ballal, A. Ashoor \& D. Jerwood. 2001. Occupational noise exposure and hearing loss of workers in two plants in eastern Saudi Arabia. Occupational Hygienic 45: 371-380.

Arce, L. \& J. Monge. 2010. Lighting and noise level in the central facilities of the Costa Rican Distance Education University: health implications for staff and students. Cuadernos de Investigación UNED 2: 63-68.

Babisch, W., B. Beule, M. Schust, N. Kersten \& H. Ising. 2005.Traffic Noise and Risk of Myocardial Infarction. Epidemiology 16: $33-40$.

Belojevi, G.A, B. D. Jakovljevi, V. J. Stojanov, V. Slepevic \& K. Paunovi. 2008. Nighttime Road-Traffic Noise and Arterial Hypertension in an Urban Population. Hypertension Research 31: 775-781.

Chacín-Almarza, B., G. Corzo-Álvarez, L. Rojas-González, E. Rodríguez-Chacín \& G. Corzo-Ríos. 2002. Estrés organizacional y exposición a ruido en trabajadores de la planta de envasado de una industria cervecera. Investigación Clínica 43: 271-289.

Chávez, R. 2006. Ruido: Efectos sobre la salud y criterio de su evaluación al interior de recintos. Ciencia y Trabajo 8: 42-46.

De Kluizenaar, Y., S.A. Janssen, F.J. van Lenthe, H.M. Miedema \& J.P Mackenbach. 2009. Long-term road traffic noise exposure is associated with an increase in morning tiredness. Journal of the Acoustics Society of America 126: 626-633.

Emanuel, E.J., D. Wendler \& C. Grady. 2000. What makes clinical research ethical? JAMA 283: 2701-2711.

Guerrero, R., F.G. Aliev, Y. Tserkovnyak, T.S. Santos \& J.S. Moodera. 2006. Shot Noise in Magnetic Tunnel Junctions: Evidence for Sequential Tunneling. Physical Review Letters 97.

Hernández, H. \& M. Gutiérrez. 2006. Hipoacusia inducida por ruido, estado actual. Revista Cubana Médica Militar 35: 4-10.

Instituto de Normas Técnicas de Costa Rica. 2000. Norma INTE 31-08-06-2000. Niveles de iluminación que deben tener los centros de trabajo. Instituto de Normas Técnicas de Costa Rica, San José, Costa Rica.

INTECO (Instituto de Normas Técnicas de Costa Rica). 2000. Norma INTE 31-09-16-2000. Condiciones de seguridad e higiene en los centros de trabajo donde se genere ruido. Instituto de Normas Técnicas de Costa Rica, San José, Costa Rica.

La Torre, G., U. Moscato, F. La Torre, P. Ballini, S. Marchi \& W. Ricciardi. 2007. Environmental noise exposure and population health: a cross-sectional study in the Province of Rome. Journal of Public Health 15: 339-344.

Loera-González, M.A., S. Salinas-Tovar, G. Aguilar-Madrid \& V.H. Borja-Aburto. 2002. Hipoacusia por trauma acústico crónico en trabajadores afiliados al IMSS, 1992-2002. Revista Médica [México] 44: 497-504. 
Montiel-López, M., G. Corzo-Alvarez, B. Chacín-Almarza, L. RojasGonzález, A. Quevedo, A. Lubo-Palma \& H. Rendiles. 2006. Prevalencia y caracterización de la pérdida auditiva en trabajadores expuestos a ruido industrial de una planta eléctrica turbogenerada en un complejo petroquímico. Investigación Clínica 47: 117-131.

Otárola, F., F. O. Zapata \& A. Finkelstein. 2008. Ruido laboral y su impacto en salud. Ciencia y Trabajo 20: 47-51.

Rodríguez, L. \& J. Alonzo. 2004. Efecto de los factores ambientales, laborales y psicosociales, en el síndrome del edificio enfermo. Ingeniería Revista Académica 8: 1-6.

Selander, J., G. Bluhm, T. Theorell, G. Pershagen, W. Babisch, I. Seiffert, D. Houthuijs, O. Breugelmans, F. Vigna-Taglianti, M. Antoniotti, E.Velonakis, E. Davou, M.Dudley \& L. Järup. 2009. Saliva Cortisol and Exposure to Aircraft Noise in Six
European Countries. Environmental Health Perspectives 117: 1713-1717.

Stansfeld, S. 2006. Exploring the Link Between Environmental Noise and Psychiatric Disorder. Psychiatric Times 23: 1-2.

Su, S., C. Lu, J. Sheen, S. Kuo \& H. Guo. 2006. Tear secretion dysfunction among women workers engaged in light-on tests in the TFT-LCD industry. BMC Public Health 6: 303-310.

Van Bommel, W. \& G. Van den Beld. 2004. Lighting for work: a review of visual and biological effects. Lighting Research and Technology 36: 255 - 269.

Wang, Y.G. \& P.P. Zhang. 2007. Study on parking apron operation hazard management. Journal of Safety and Environment 7: 131-133.

Article edited by Vanessa Nielsen 